\title{
Ultrasound-Guided Percutaneous Removal of Foreign Body Using Hydrodissection and Serial Dilators
}

\author{
Sung Moon Lee, M.D., Ph.D.*, and Chul-Hyun Cho, M.D., Ph.D. \\ Departments of Orthopaedic Surgery, ${ }^{\star}$ Radiology, School of Medicine, Keimyung University, Daegu, Korea
}

\begin{abstract}
High-resolution ultrasound of the painful, swollen left heel of a 54-year-old man, who reported that his symptoms had lasted 4 months, showed retention of a wooden foreign body in the heel. After administering local anesthesia and making a 5-mm skin incision, we performed hydrodissection of the foreign body from the adjacent soft tissue under real-time ultrasound guidance, using a $1 \%$ lidocaine solution. Then, we introduced an 18-gauge spinal needle and inserted a guide-wire through the needle. After we removed the needle, we introduced serial dilators in sizes ranging from 7 French to 12 French along the guide-wire to create a tract for mosquito forceps. Then, we introduced the mosquito forceps and removed the wooden foreign body. Ultrasound-guided percutaneous removal of foreign bodies is quick and safe. We believe that hydrodissection makes removal easier and that use of serial dilators minimizes soft-tissue injury and makes it easier to introduce mosquito forceps.
\end{abstract}

Key words: foreign bodies, percutaneous removal, ultrasound

Foreign bodies retained in soft tissue represent a common troublesome problem for physicians because they are easy to misdiagnose. Plain radiographs have been used to identify radiopaque foreign bodies, and fluoroscopy has been used for guidance during surgical removal. ${ }^{1)}$ When the foreign body is not radiopaque, however, as, for example, a wooden object or a thorn, it may remain undetected even after exploration. High-resolution, real-time ultrasound has proved to be both sensitive and specific when used to detect and remove radiolucent foreign bodies. Recent reports have demonstrated the usefulness of ultrasound in the detection, preoperative localization, and confirmation of surgical retrieval of radiolucent foreign bodies in the extremities. ${ }^{2-5}$ Several authors have reported that ultrasound-guided removal is a good alternative to surgery. ${ }^{3,6,7)}$ However, there are few reports of useful methods or techniques for such removal. Therefore, we present here a useful technique for ultrasound-guided removal of foreign bodies using hydrodissection of the problematic objects and serial dilators for creating a tract for

\section{Received October 20, 2011 Revised October 24, 2011}

Accepted October 25, 2011

Correspondence to: Chul-Hyun Cho, M.D., Ph.D.

Department of Orthopaedic Surgery, Dongsan Medical Center, School of Medicine, Keimyung University, 56, Dalseong-ro, Jung-gu, Daegu 700-712, Korea

TEL: +82-53-250-7729 FAX: +82-53-250-7205 E-mail: 0scho5362@dsmc.or.kr their removal.

\section{CASE REPORT}

A 54-year-old man was referred to our hospital with a history of pain and swelling in his left foot. About 4 months earlier, he sus-

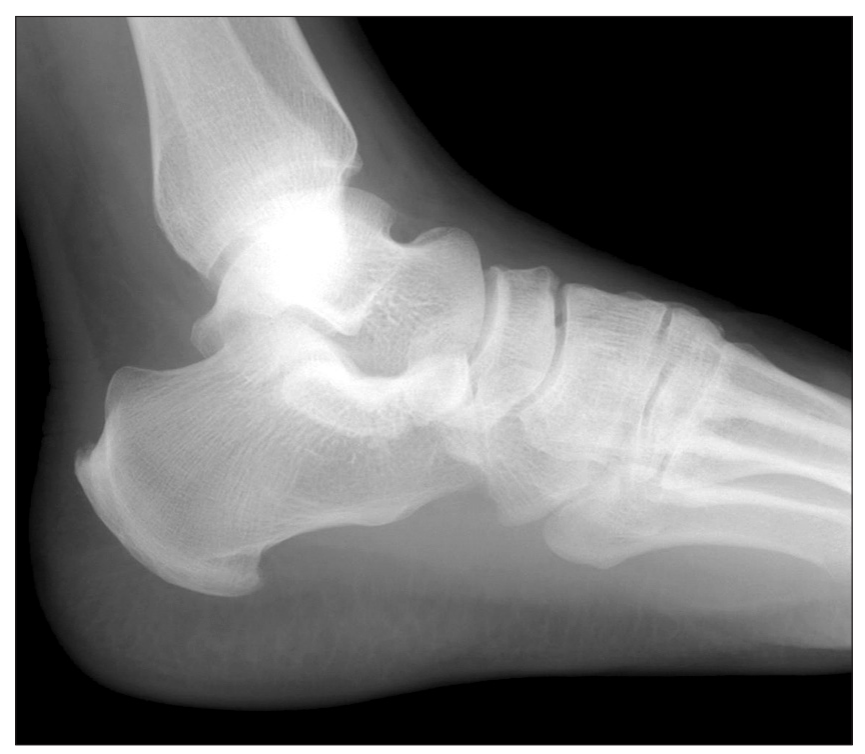

Figure 1. A lateral plain radiograph of the left foot reveals diffuse softtissue swelling around the heel area but no evidence of a foreign body.

대한정형외과학회지 : 제 47권 제 2호 2012 Copyright @ 2012 by The Korean Orthopaedic Association

"This is an Open Access article distributed under the terms of the Creative Commons Attribution Non-Commercial License (http://creativecommons.org/licenses/by-nc/3.0/) which permits unrestricted non-commercial use, distribution, and reproduction in any medium, provided the original work is properly cited. 
Ultrasound-Guided Percutaneous Removal of Foreign Body
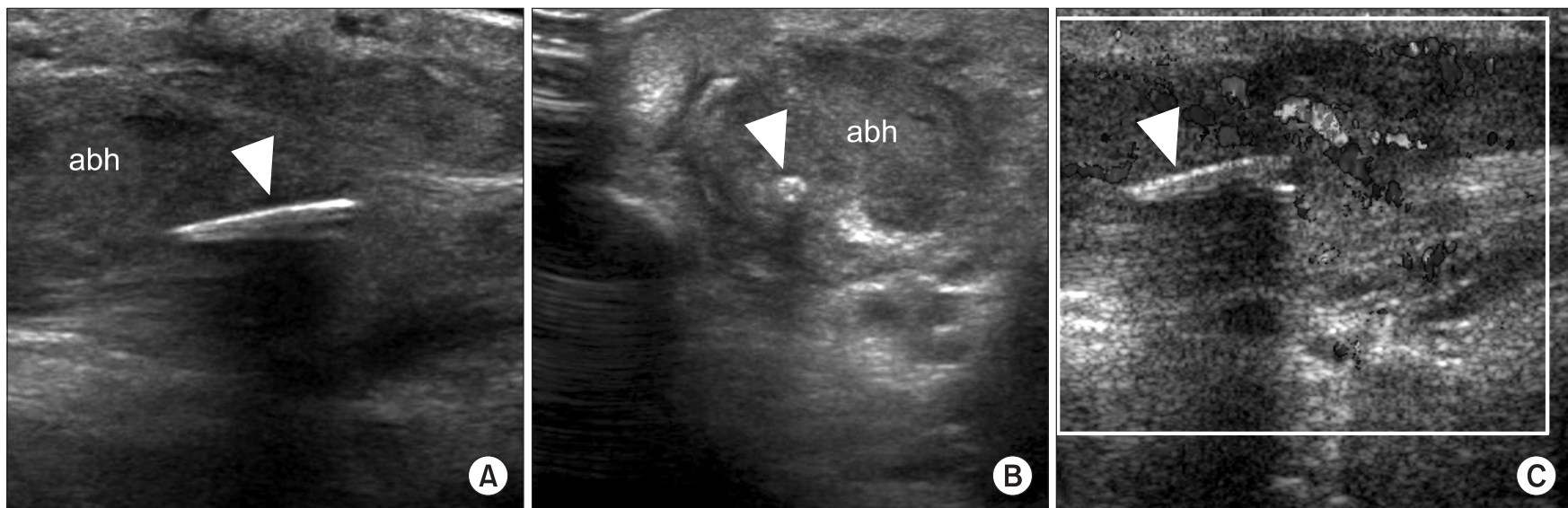

Figure 2. Longitudinal (A) and transverse (B) ultrasound scan images show a linear hyperechoic foreign body (arrowheads) with underlying acoustic shadowing within the abductor hallucis muscle (abh). (C) Color Doppler scan shows increased vascularity of the abductor hallucis muscle contained foreign body (arrowheads).
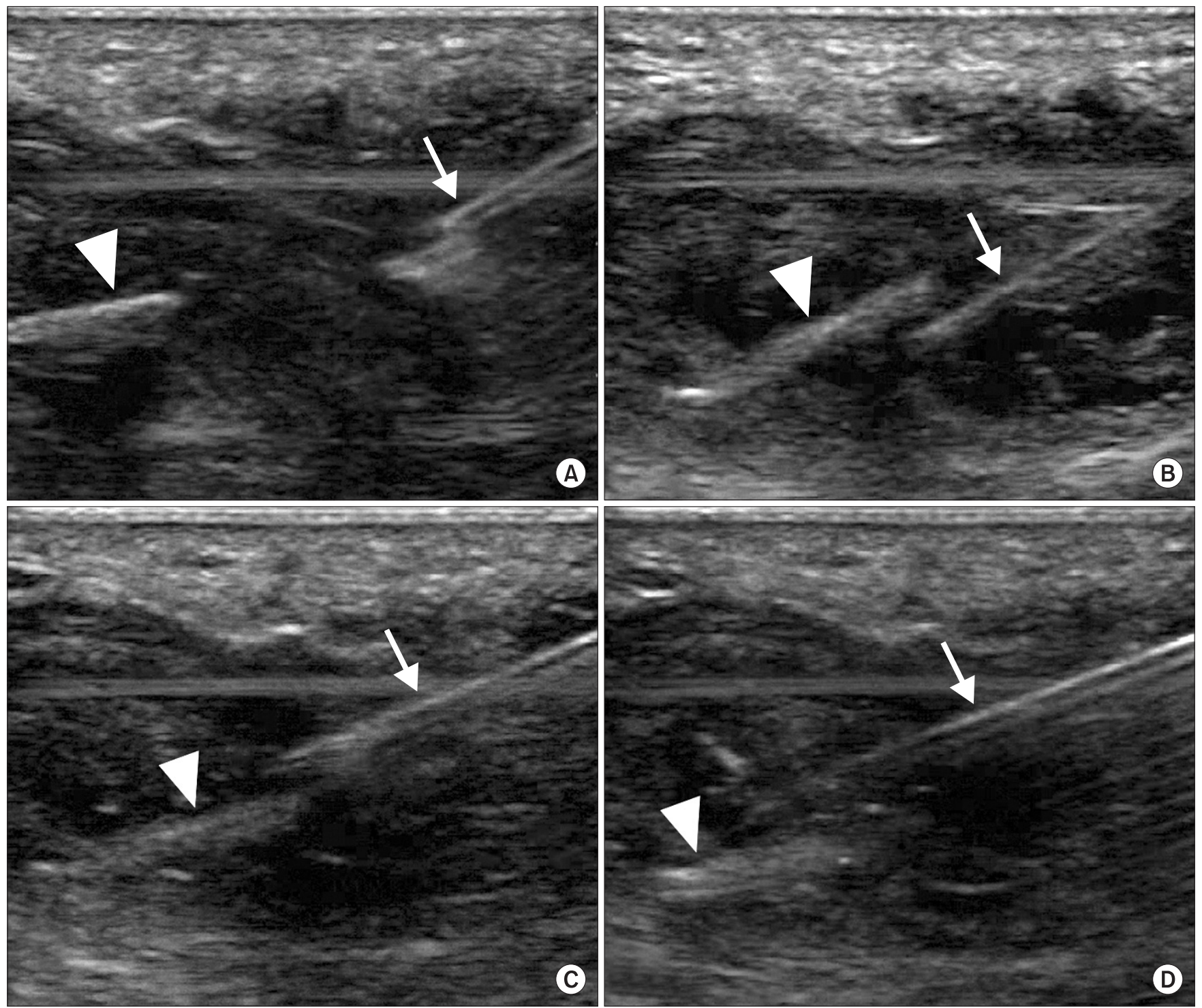

Figure 3. Longitudinal scan images show hydrodissection using 18-gauge spinal needle (white arrows) with 1\% lidocaine solution deep to (A, B) and superficial to (C, D) the foreign body (arrowheads) to make easier removal. 

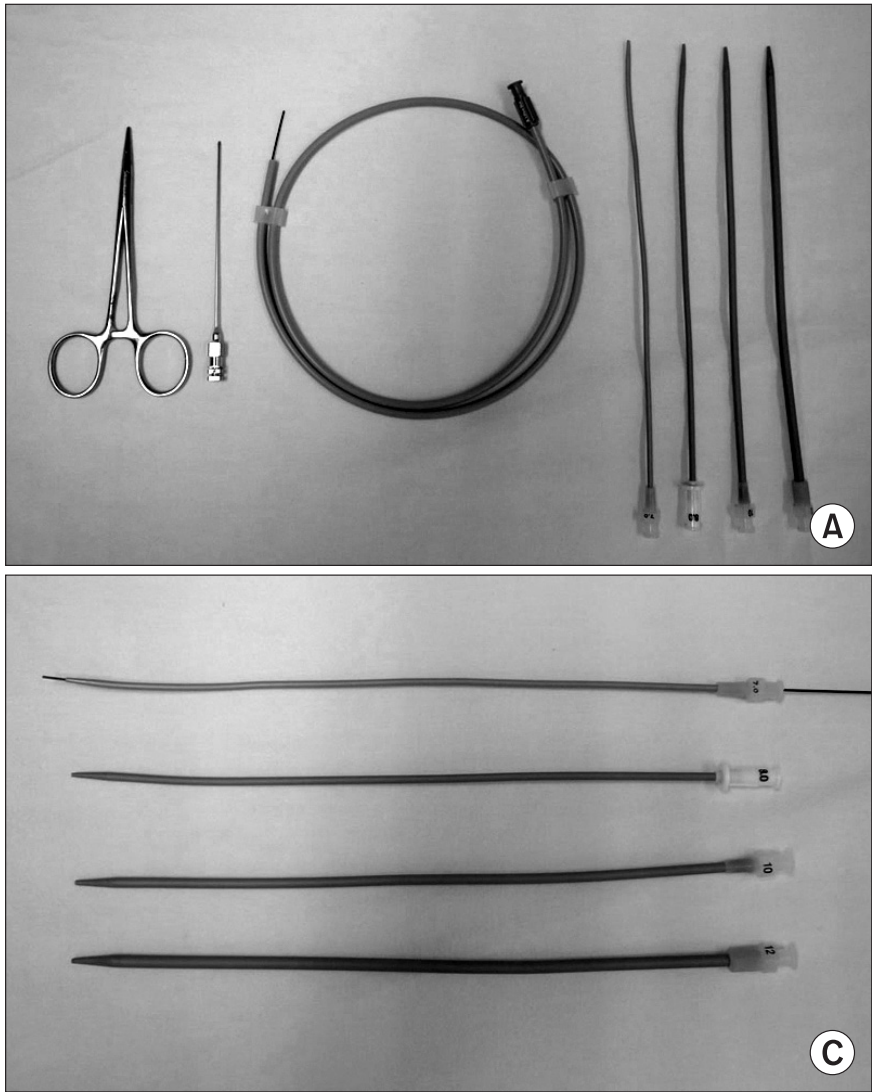

tained a stab injury from a rusted nail in a construction area and had the nail removed from his foot immediately. He visited a local clinic and was given oral antibiotics to take for 2 weeks. The puncture wound healed, but his symptoms persisted. On physical examination, diffuse erythematous swelling and marked tenderness over the medial aspect of his left heel was observed.

Plain radiographs revealed diffuse soft tissue swelling around heel area. No destructive bony lesion or foreign body was identified (Fig. 1). Ultrasound examination (ATL HDI 5000, Philips Medical Systems, Bothell, WA, USA) with a real-time, high-resolution linear transducer $(7-15 \mathrm{MHz})$ revealed a linear hyperechoic structure with underlying acoustic shadowing within the abductor hallucis muscle $9 \mathrm{~mm}$ in length and $2.5 \mathrm{~mm}$ in diameter. We believed the foreign body to be made of wood. The depth of the foreign body from the skin was $1.5 \mathrm{~cm}$ (Fig. 2).

We made plans for ultrasound-guided percutaneous removal of the foreign body. After sterile skin preparation, local anesthesia with $1 \%$ lidocaine solution was administered. Using ultrasound guidance, we made a 5-mm skin incision at the site where the long axis of a 23-gauge needle and the foreign body were parallel as possible as. To make removal of the foreign body easier, we used hydrodissection from the adjacent soft tissue using a $1 \%$ lidocaine solution (Fig.

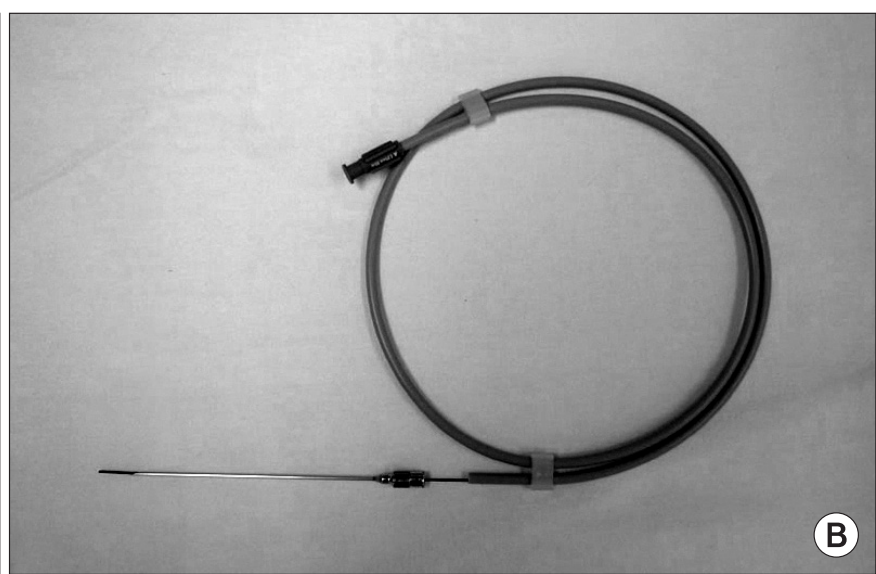

Figure 4. (A) Instruments used to create a tract for introducing mosquito forceps using dilators: mosquito forceps, 18-gauge spinal needle, guidewire, dilators. (B) After hydrodissection, an 18-gauge spinal needle was introduced and a guide-wire was inserted through it. (C) After removal of the spinal needle, serial dilators, from 7 French to 12 French, were introduced along the guide-wire to create a tract for the introduction of mosquito forceps, which minimized further soft-tissue injury.

3). After hydrodissection, we introduced an 18-gauge spinal needle and inserted a guide-wire through it. We then introduced serial dilators, from 7 French to 12 French, along the guide-wire to create a tract for introducing mosquito forceps (Fig. 4). We were able to remove a wooden foreign body with the forceps (Fig. 5). All procedures were performed under ultrasound guidance, and the total time required was approximately 20 minutes. There were no significant complications during or after the procedure. At a follow-up examination 4 weeks later, the patient reported being symptom free, and there was no clinical evidence of symptom recurrence.

\section{DISCUSSION}

Detection of foreign bodies retained in soft tissue is often very difficult, even when their presence is strongly suggested by patients' medical history and physical examination findings. Radiopaque foreign bodies such as glass, metal, and stone can be identified on plain radiographs, but radiolucent foreign bodies such as wood frequently remain undetected. Undetected wooden foreign bodies can cause significant morbidity, chronic drainage, abscesses, persistent pain, and even devitalization of tissue and destruction of the bone or joint, in addition to repeat hospital visits, high costs, and extensive surgery. 

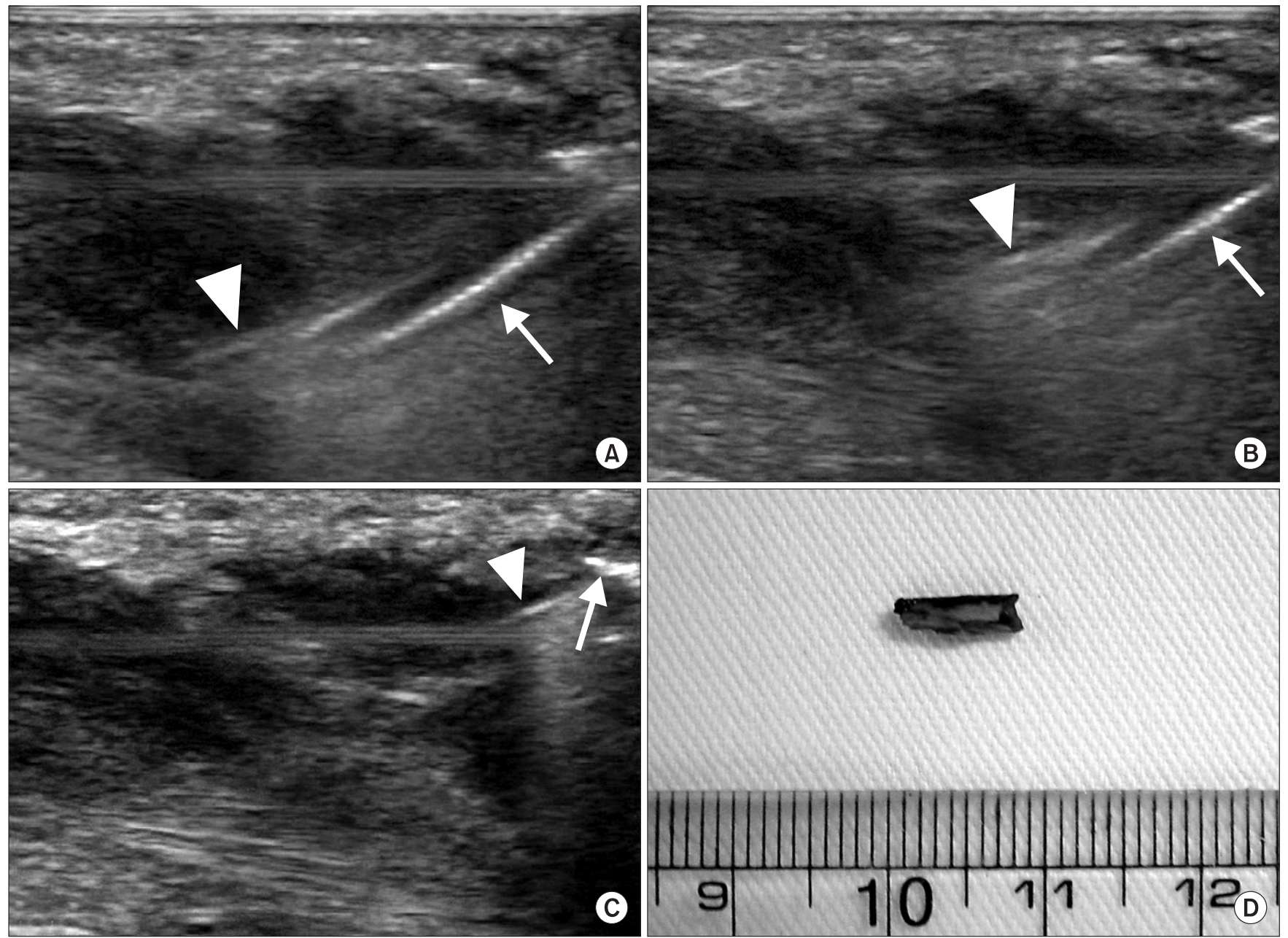

Figure 5. (A-C) Serial ultrasound images of removal of the foreign body (arrowheads) with mosquito forceps (white arrows). (D) Removed wooden foreign body.

Because the symptoms after the initial injury persisted in our patient for 4 months and because he had marked tenderness over the medial aspect of the left heel, we strongly suspected the presence of a foreign body, especially after obtaining a thorough medical history taking and conducting a physical examination. The wooden foreign body was detectable by high-resolution ultrasound.

Ultrasound examination is an excellent alternative tool for identifying radiolucent foreign bodies. It can provide accurate information about depth, size, and anatomic relationships. High-resolution, real-time ultrasound is the first choice for investigation for a foreign body retained in soft tissue, as it has a sensitivity of $90 \%$ and a specificity of $96 \%{ }^{2)}$ Recent reports have demonstrated the usefulness of ultrasound in the detection, preoperative localization, and confirmation of surgical retrieval of radiolucent foreign bodies in the extremities. $^{2-5)}$

However, removing these foreign bodies is still a problem. Surgical removal is invasive, costly, and technically challenging. The pro- cedure may fail in some cases and carries the risk of complications. Ultrasound-guided removal is a good alternative to surgery because it is relatively straightforward, inexpensive, and repeatable and carries a low risk of complications. ${ }^{2,7}$

Ultrasound-guided dissection and removal of foreign bodies allows tailoring of the surgical approach and reduction of incision size and dissection depth. Preoperative ultrasound is an essential element in successful detection, localization, and guided removal of foreign bodies. ${ }^{1)}$ The localization is accomplished by using anatomic landmarks, pen marks on the skin, needle markers, and small standoff pads.

Few authors have reported useful methods for ultrasound-guided removal of foreign bodies from soft tissue. Shiels et $\mathrm{al}^{1)}$ reported that the operator uses his or her dominant hand to insert the surgical forceps through the incision to reach the foreign body, following its passage in real time on longitudinal ultrasound scan. They said that the arms of the hemostat are then opened slightly, displacing 
Sung Moon Lee and Chul-Hyun Cho

the tissue surrounding the foreign body, to grip the object and then remove it. Scanning with the ultrasound beam parallel to the long axis of the hemostat and the foreign body is, they noted, the fastest way to guide the hemostat to the tip of a foreign body. Alternatively, Schlager ${ }^{7)}$ reported that a needle tip can be directed by ultrasound to the foreign body, and the incision can then be made down to the needle tip. Using real-time imaging, the author noted, needle position can be continuously directed in relation to the object to aid retrieval. This technique is advantageous for foreign bodies that can move or roll.

A combination of longitudinal and transverse scanning planes facilitates removal. Scanning with the ultrasound beam aligned with the long axis of a hemostat and the foreign body is the fastest way to guide the hemostat to the tip of the foreign body. If the removal attempt with longitudinal scanning is unsuccessful, then after the closed hemostat is visualized near the tip of the foreign body, transverse scanning best shows the tip of the foreign body as well as the two tips of the hemostat, in open and closed positions. ${ }^{1)}$ In most cases, injection of the anesthetic close to the foreign body will detach it from the surrounding tissues, thereby facilitating subsequent removal. Anesthetic should continue to be injected while the needle is retracted, to anesthetize the needle path to be used during removal. ${ }^{2)}$

Our two useful techniques of ultrasound-guided removal are hydrodissection of the foreign body and use of dilators to create a tract for removal of the foreign body. Hydrodissection is the more useful technique for foreign bodies that have been retained for quite some time, as with our patient. Using a guide-wire and serial dilators to create a tract might be helpful when introduction of mosquito forceps is necessary and may minimize soft-tissue injury. The technique is minimally invasive, as its point entry is a simple skin incision of usually less than $1 \mathrm{~cm}$ and the small residual scar has little esthetic impact. So our technique can be available at any location and depth, if ultrasound-guided approach is accessible.

Our procedure for removing foreign bodies from soft tissue can be summarized as follows: (1) identification and localization of the foreign body, (2) provision of local anesthesia and hydrodissection of the foreign body using 1\% lidocaine solution, (3) creation of a tract for introducing mosquito forceps using a guidewire and serial dilator, and (4) introduction of mosquito forceps through the tract and removal of the foreign body.

Ultrasound-guided percutaneous removal of foreign bodies is quick and safe. We believe that hydrodissection makes removal easier and that use of serial dilators minimizes soft-tissue injury and makes it easier to introduce mosquito forceps.

\section{REFERENCES}

1. Shiels WE 2nd, Babcock DS, Wilson JL, Burch RA. Localization and guided removal of soft-tissue foreign bodies with sonography. AJR Am J Roentgenol. 1990;155:1277-81.

2. Callegari L, Leonardi A, Bini A, et al. Ultrasound-guided removal of foreign bodies: personal experience. Eur Radiol. 2009;19:1273-9.

3. Blankstein A, Cohen I, Heiman Z, Salai M, Heim M, Chechick A. Localization, detection and guided removal of soft tissue in the hands using sonography. Arch Orthop Trauma Surg. 2000;120:514-7.

4. Graham DD Jr. Ultrasound in the emergency department: detection of wooden foreign bodies in the soft tissues. J Emerg Med. 2002;22:75-9.

5. Leung A, Patton A, Navoy J, Cummings RJ. Intraoperative sonography-guided removal of radiolucent foreign bodies. J Pediatr Orthop. 1998;18:259-61.

6. Turner J, Wilde CH, Hughes KC, Meilstrup JW, Manders EK. Ultrasound-guided retrieval of small foreign objects in subcutaneous tissue. Ann Emerg Med. 1997;29:731-4.

7. Schlager D. Ultrasound detection of foreign bodies and procedure guidance. Emerg Med Clin North Am. 1997;15:895-912. 


\title{
Hydrodissection 및 Serial Dilator를 이용한 초음파하 경피적 이물 제거술
}

\author{
이성문 $•$ 조철현
}

계명대학교 의과대학 정형외과학교실, ${ }^{*}$ 영상의학과학교실

4 개월간의 좌측 후족부 동통 및 종창을 주소로 내원한 54 세 남자에서 고해상도 초음파 검사상 좌측 후족부에 나무 양상의 이물이 관 찰되었다. 국소 마취제를 투여하고 $5 \mathrm{~mm}$ 가량의 피부 절개 후 실시간 초음파하에 $1 \%$ lidocaine 용액을 이용하여 이물과 주위 연부 조직을 박리하기 위해 hydrodissection을 시행하였다. 그 후 18-gauge spinal needle과 guide-wire를 삽입한 다음 needle을 빼내고, 이물을 쉽게 빼내기 위해 7에서 12 French의 guide-wire를 차례로 삽입한 다음 mosquito forceps를 이용하여 이물을 제거하였다. Hydrodissection 및 serial dilator를 이용한 초음파하 경피적 이물 제거술은 빠르고 안전한 방법이라 생각한다.

색인단어: 이물, 경피적 제거술, 초음파하

접수일 2011년 10월 20일 수정일 2011년 10월 24일 게재확정일 2011년 10월 25일 교신저자 조철현

대구시중구 달성로 56 , 계명대학교 동산의료원 정형오과학교실

TEL 053-250-7729, FAX 053-250-7205, E-mail oscho5362@dsmc.or.kr 